\title{
КОМПЛЕКС ТАКТИЧНИХ ЛІНІЙ РОЗГОРТАННЯ І КОМУНІКАТИВНИХ ХОДІВ УТІЛЕННЯ ПУБЛІЧНИХ ВИСТУПІВ ПРЕЗИДЕНТІВ СПОЛУЧЕНИХ ШТАТІВ
}

У статті досліджуються такі важливі складові частини втілення провідної стратегї англомовного президентського виступу, як комунікативні тактики й комунікативні ходи, ієрархічну супідрядність яких встановлено на основі методологічних принциипів.

Базисом створення та особливості розгортання тактичних ліній президентської комунікації в жанрі звернення до нації опосередковано аксіологічними моделями презентації референтної ситуації та пов'язаних із нею об'єкта й суб'єкта промови. Іншою ознакою, згідно з проведеним аналізом типологій комунікативних стратегій і тактик, слід вважати консолідаційну складову частину, тобто комплекс мовленнєвих ходів, апелятивна сила яких, об’єднуючи слухачів довкола певної ідеї, здатна мобілізувати їхню сочіально-політичну свідомість.

Комунікативне розгортання повідомлюваного з огляду на втілювані президентом настанови позитивного, негативного чи нейтрального характеру, описано як тактичні лінії: 1) акцентування на позитивних рисах об'єкта чи референтної ситуаиї промови, 2) акцентування на негативних рисах об 'єкта чи референтної ситуації промови й 3) театральності.

На підставі цьвого було сформовано інвентар комунікативних ходів, функиіонування яких забезпечує актуалізацію комунікативної стратегії збереження іміджу шляхом формування суспільної думки. До переліку найтиповіших віднесено такі комунікативні ходи: самопрезентащію, відведення критики, аналіз-«плюс», аналіз-«мінус», викриття, звинувачення, спонукання, застереження, коопераџію та обіияння.

Проведений аналіз дозволяє пересвідчитися, щүо інвентар засобів реалізації інтениійної складової частини досліджуваних президентських звернень досить адекватно інтерпретується визначеною сукупністю комунікативних тактик і ходів. Їхній комплекс - власне, динамічні зміни й поєднання комунікативних ходів - дозволяє президенту-мовцюю залежно від його когнітивної бази, прагматичних настанов і певних ситуативних факторів позалінгвального порядку здійснювати загострення уваги слухача на ключових ділянках промови, створювати потрібні ціннісні орієнтири й викликати певні очікувані реакції з боку аудиторії.

Ключові слова: комунікативна тактика, комунікативний хід, стратегія, президентське звернення, тактична лінія.

Valerii SAVCHUK, orcid.org/0000-0001-9630-3636 Lecturer at the Department of Foreign Philology,

Translation and Teaching Methodology

Hryhoriy Skovoroda University in Pereyaslav (Pereiaslav, Kyiv region, Ukraine) valeriy_savchuk@ukr.net

\section{A COMPLEX OF TACTICAL LINES AND COMMUNICATIVE MOVES IMPLEMENTING PUBLIC SPEECHES OF THE PRESIDENTS OF THE UNITED STATES}

The article studies such important components of the leading strategy in English presidential speeches as communicative tactics and communicative moves, the hierarchical subordination of which has been defined on the basis of methodological principles.

It is axiological models of reference situation representation and the situation determined object and subject of speech that are fundamental for creation and further development of tactical lines of presidential communication in the addresses to the nation. The analysis of typologies of communicative strategies and tactics shows that another important feature is a consolidating component, i.e. a set of communicative moves whose appellative power unite listeners around a particular idea and is able to mobilize their socio-political consciousness.

A speech delivery process, depending on the type of intention the president exploits, positive, negative or neutral, is described as three tactical lines: 1) emphasizing positive features of the object or reference situation of speech, 2) emphasizing negative features of the object or reference situation of speech, and 3) the tactical line of theatricality. 
This enables us to make a complex of communicative moves effectively contributing to the actualization of the communicative strategy of image preservation by shaping public opinion. The list of the typical communicative moves includes: self-presentation, criticism, analysis-"plus", analysis-"minus', exposure, accusation, motivation, warning, cooperation and promise.

Our findings allow us to make sure that the inventory of means of intentional component realization in the researched presidential addresses is adequately interpreted by a certain set of communicative tactics and moves. This complex, dynamic changes and combination of communicative moves, allows the president, depending on his cognitive base, pragmatic intentions and certain situational factors of non-linguistic level, to focus the listener's attention on key areas of the speech, highlight necessary values and evoke some expected reactions from the audience.

Key words: communicative tactic, communicative move, strategy, presidential address, tactical line.

Постановка проблеми. Публічний політичний дискурс, власне, публічна комунікація лідерів держави, $\epsilon$, безсумнівно, одним із магістральних компонентів сучасного медіа, що визначає пріоритети розбудови соціально значущих сфер, значною мірою впливає на суспільний устрій і тією ж мірою формує та нав'язує способи інтерпретації картини світу. Цілком природно, що така потужна сила породжує зацікавленість до розуміння форм, методів, засобів і прийомів побудови ефективних мовленнєвих зразків із високим сугестивно-прагматичним потенціалом. Прикметним у контексті цього є зосередження на вивченні глибинних механізмів породження мовленнєвого витвору й подальшого забарвлення експресивно-ефектними барвами переконування, де примат першості посідають студії, зорієнтовані на проблему стратегій, тактик та інших одиниць нижчого ієрархічного рівня.

Зазначене вище дає підстави визначити пріоритетність дослідження в розрізі аналізу засобів втілення ключових складників комунікативної стратегіï. Варто зазначити, що попередній розгляд алгоритму iї розгортання, як і природи й особливостей втілення в президентських зверненнях (див. дет. Савчук, 2017: 148), зумовив потребу подальшої деталізації специфіки актуалізації стратегії іiі складовими частинами, а саме комунікативними тактиками й ходами.

Аналіз досліджень. Цілком природно, що подібна проблематика широко, й мало того, досить детально викладена в науковій літературі. Лінгвісти розглядають і загальні закономірності функціонування стратегій і тактик (О. Й. Шейгал, R. Wodak), i конкретні аспекти втілення їхніх окремих складових частин (О.В.Горіна, О.В.Гайкова, Н. В. Петлюченко й інші). Разом із тим актуальним залишається питання систематизації знань про особливості стратегічно-тактичного шару президентської промови в такому важливому жанрі 3 боку частоти виголошування, як звернення.

Мета статті - визначення інвентарю тактичних ліній і комунікативних ходів для втілення провідної в англомовних президентських зверненнях стратегії збереження іміджу шляхом формування суспільної думки.

Виклад основного матеріалу. Для визначення тактичних ліній втілення досліджуваної стратегії доцільно звернутися до відомих у спеціальній літературі класифікацій комунікативних стратегій і тактик (Иссерс, 2003; Паршина, 2005; Горіна, 2008 та інші). Стислий аналіз засвідчує певну варіативність цих типологій, зумовлену насамперед конкретним аспектом чи підходом їхнього дослідження.

Так, О. Й. Шейгал розглядає стратегії вуалювання, затушовування небажаної інформації; містифікації, покликаної приховувати істину; анонімності як прийому зняття відповідальності (Шейгал, 2004: 137), зосереджуючись таким чином на способах оптимізації та підтримці іміджевих характеристик шляхом відведення критики, прагматична орієнтація чого покликана змінити ставлення слухача до загрозливої для іміджу ситуації. У загальних рисах це можна представити у вигляді схеми: мовець $\rightarrow$ мінімізація відповідальності $=$ негативних суджень $\rightarrow$ слухач. Цю особливість відбито й в інших дослідженнях. Зокрема, О. С. Іссерс на основі аналізу письмових текстів засобів масової інформації пропонує стратегії дискредитації та самопрезентації (Иссерс, 2003). Подібні різновиди (дискредитації та самореклами в складі маніпулятивної стратегії) виділяє О. В. Гайкова (Гайкова, 2003: 81), аналізуючи передвиборчі виступи Дж. Буша й А. Гора.

Навіть на перший погляд неважко переконатися, що спільними з боку особливостей формування дискурсивної реальності для наведених вище класифікацій $є$ полярність векторів реалізації мовленнєвої поведінки адресанта: підвищення власного статусу на фоні пониження статусу опонента. Виконуючи роль фільтра, ця опозиція маркує семантику стратегічно вагомих квантів інформації, зміщуючи їхні конотативні характеристики в площину або позитивної, або негативної оцінки, що цілком природно збільшує частку негативно чи позитивно-оцінних номінацій. 
Інтеграція мовних засобів до однієї із зазначених площин наділяе їх високим сугестивним потенціалом (Шейгал, 2004: 107), сприяє появі яскравих образних асоціацій, активізує сильні емоції та таким чином викликає бажану реакцію, здійснює швидку категоризацію понять у свідомості реципієнта й таке інше. Цікавим видається також те, що роль створення подібної модальності за відсутності її прямої експлікації лексичними одиницями мови виконують засоби просодичного рівня. Так, наприклад, у праці (Федорів, 2010: 118) згадується прийом непрямого або прихованого навіювання, який, структуруючи повідомлення особливим чином, транслює закодовані команди. Цей прийом, на думку авторки, реалізується шляхом слабких варіювань тонального рівня голосу на ключових ділянках висловлення. Ефект його використання значно інтенсифікується хезитаційними паузами, які в поєднанні зі зниженням тонального рівня перед ключовими словами не фіксуються свідомістю, проте спричиняють маніпулювання діями слухача (Федорів, 2010: 119). I це закономірно, оскільки в теоретичних студіях рекламного дискурсу давно відомо, що краще засвоюється імпліцитна інформація, виокремлювана реципієнтом iз контексту висловлювання, та, бувши спрямованою безпосередньо в підсвідомість, сприймається як єдино правильна істина.

Ширший арсенал стратегій, який містить самопрезентацію, дискредитацію, напад, самозахист, формування емоційного настрою адресата, інформаційно-інтерпретаційну, аргументативну, агітаційну й маніпулятивну дію, знаходимо в роботі (Паршина, 2006: 302). Очевидно, що подібне розмаїття також представляє зазначену вище базову полярну векторність мовленнєвої поведінки політика. Разом із тим це свідчить і про значну частку прагма-мапіпулятивної складової частини в президентській риториці, позначеної в іншому дослідженні (Горіна, 2008: 13), крім деяких зазначених вище, також стратегіями спонукання та маніпулювання, тоді як у вже згадуваному джерелі (Гайкова, 2003: 101, 106) ця складова частина представлена окремою аргументативною стратегією $з$ двома підвидами (раціональної та емоційної аргументації).

Абстрагуючись від відмінностей використовуваного термінологічного апарату зазначеними авторами, суттєвою видається переважна орієнтація цих різновидів стратегії на заклик, загострення уваги на наявних чи / або можливих загрозах, обіцянках, тобто способах, покликаних збуджувати когнітивну діяльність психіки слухача. Це, безумовно, підводить нас до розуміння вагомості апе- ляції до системи цінностей, стереотипів, логіки реципієнта, іншими словами, прямого звернення до сфери свідомості адресата.

Таким чином, проведений аналіз, на перший погляд, значно диверсифікованих типологій комунікативних стратегій виявляє низку типових властивостей, здатних справляти ефективний вплив на колективну свідомість, які згідно з прийнятим нами алгоритмом розгортання комунікативної стратегії цілком природно відбивають універсальні тактичні лінії. Насамперед це створення аксіологічних моделей презентації референтної ситуації та пов'язаних із нею об'єкта й суб'єкта промови. Іншою ознакою, згідно $з$ проведеним аналізом типологій комунікативних стратегій i тактик, слід вважати консолідаційну складову частину, тобто комплекс мовленнєвих ходів, апелятивна сила яких, об'єднуючи слухачів довкола певної ідеї, здатна мобілізувати їхню соціальнополітичну свідомість, наприклад, заклики до кооперації, обіцянки, застереження тощо.

На аксіологічності як одному 3 провідних компонентів організації сучасного політичного дискурсу наголошується рядом дослідників (Петлюченко, 2009: 112), зокрема в риториці американських політиків. Так, авторкою (Фоменко, 1998: 4) підкреслюється, що представлені здебільшого лексемами найважливіші ціннісні поняття фактично виконують роль аргументем, справляючи помітний вплив на когнітивну систему реципієнта. Подібна думка висловлюється також у роботі (Славова, 2010: 92), де зауважується, що «семантичне наповнення та прагматика президентського дискурсу, які подекуди тяжіють до надання оцінки, схвалення предмету мовлення та такого іншого, зумовлюють його зв' язок із ціннісними орієнтаціями в суспільстві, внаслідок чого значну частку використовуваних мовцем стратегій складають аксіологічні стратегії» (Славова, 2010: 92).

3 цього слідує, що конститутивні ознаки специфіки мовного вираження використовуваних президентом тактик слід вбачати у висловленні ціннісного змісту, власне, створенні аксіологічної перспективи, що ефективно впливає на сприйняття повідомлення реципієнтом.

Таким чином, примат аксіологічності, на яку особливо реагує аудиторія та визначає враження від лідера, дає підстави вважати, що наведені вище класифікації, як і будь-яка інша, неминуче спиратимуться на конституювання референціальних об'єктів промови як експліцитну чи імпліцитну бінарну гіперонімічну опозицію «свій / добро» (правильний - створення позитивного образу 
в картині світу реципієнта) й «чужий / зло» (неправильний - закладає підвалини для формування негативного ставлення до об'єкта промови) (Петлюченко, 2009: 112).

Водночас необхідно звернути увагу на те, що властива здебільшого промовам агональної жанрової площини політичної комунікації опозиція «ми - вони» навряд чи може бути експлікована тією ж мірою в досліджуваних зверненнях орієнтаційних жанрів, що апріорі унеможливлює існування деяких комунікативних ходів, як-от дискредитація, провокація та таке інше. Це своєю чергою мінімізує маркованість стратегічно-тактичних складових частин промови пейоративністю, інвективністю, дискредитаційністю тощо.

Разом із тим детальний аналіз цього питання свідчить про фундаментальність дихотомії також і для досліджуваного жанру президентських звернень. За відсутності прямого опонента подібна опозиція представлена об'єктом «ми», традиційно інтегрувального образ слухача й президента, тоді як об'єкт «вони» відповідає одній із можливих загроз, на які не просто реагує будь-який громадянин, але й складає цілі області страху, що стали вже традиційними для американського суспільства. Вони продиктовані цілою низкою загроз: зовнішні (світове зло, тероризм, антидемократичний політичний діяч-диктатор), внутрішні (порушення демократичних принципів, хаос, крах системи, спад у будь-якій із галузей), особистісні

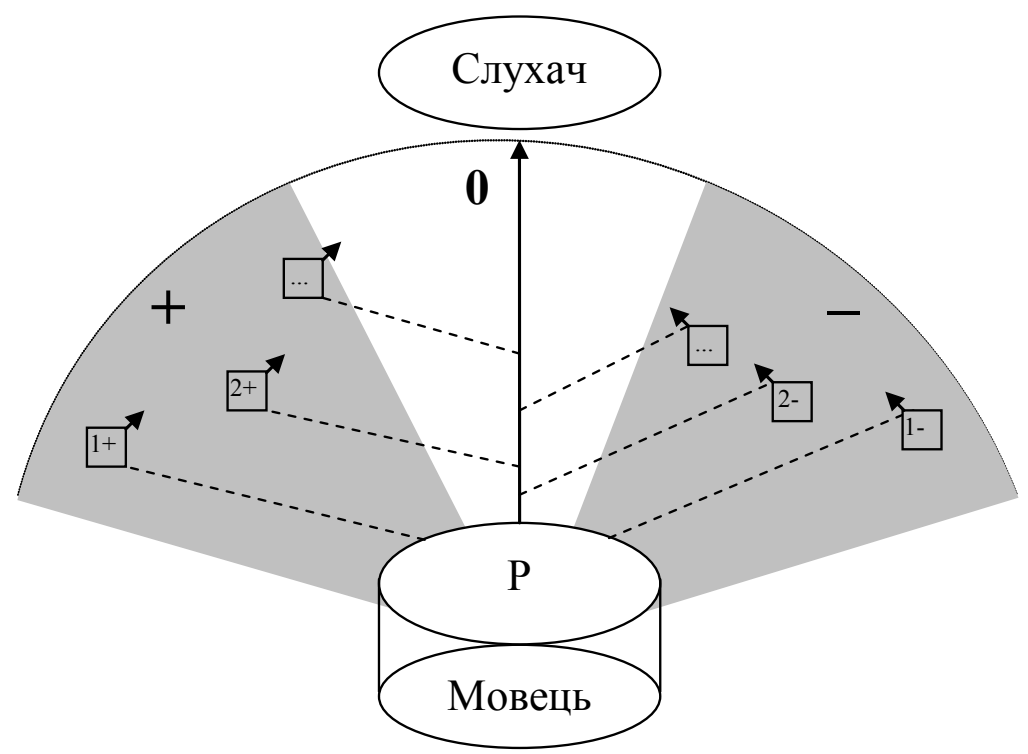

Рис. 1. Модель розгортання тактичних ліній комунікативної стратегії збереження іміджу шляхом формування суспільної думки у зверненнях президентів США

Умовні позначки: Р - референтна ситуація / об’єкт промови; « $\rightarrow »-$ вектор інтеграції висловлень до: «+» - площини позитивної презентації повідомлюваного, «-» - площини негативної презентації повідомлюваного, «0» - площини нейтральної презентації повідомлюваного (порушення власного добробуту, страх помилкових рішень) і такі інші (Chaput, 2010: 1).

Отже, зважаючи на позитивну й / або негативну оцінювальність і апелятивність як основні параметри диференціації типів комунікативних тактик і виходячи 3 наявної градації фатичних інтенцій, спрямованих на покращення, погіршення чи збереження взаємостосунків у загальному просторі мовленнєвої поведінки комунікантів (Дементьев, 1997), яка також відбивається і в закономірності функціонування вербальних знаків семіотичного простору політичного дискурсу (Шейгал, 2004: 114-133), де група «ми», ототожнювана насамперед із мовцем, зображається виключно в позитивному світлі, позаяк група «вони / інші = загроза» може бути диференційована за шкалою нейтральної, позитивної чи негативної оцінки (Wodak, 2011: 40-43), можемо дати досить об'єктивних підстав визначити їхній арсенал у кількості трьох укрупнених варіантів, представлених на рис. 1 як позитивна, негативна й нейтральна градації. Отриманий таким чином комплекс тактичних складових частин президентського звернення здатен слугувати логічним орієнтиром для розгляду особливостей їхнього функціонування в досліджуваних президентських зверненнях та обгрунтування наступного рівня шуканого інвентарю комунікативних ходів.

Подальший розгляд специфіки їхньої вербальної маніфестації дозволяє уявляти наведену на рис. 1 модель розгортання тактичних ліній досліджуваної комунікативної стратегії за певною матрицею їхньої актуалізації комунікативними ходами (далі - КX).

Вихідним моментом моделі слугує відома технологія здійснення комунікативного акту (Бацевич, 2004: 104), яка охоплює такізагальніпроцедури, як відправлення повідомлення мовцем, його реалізація через канал зв'язку, а також отримання та обробка реципієнтом.

Зважаючи на те, що суб'єкту висловлення та його мовній реалізації належить центральне місце простору дискурсії (Wodak, 2011: 40), а його експлікація може бути прямою з фокусом на результати діяльності, досягнення тощо або імпліцитною опосередкованою аналізом референтної ситуації / предмета мовлення, на рисунку цей зв'язок зображено двома сферами мовця як вихідної бази акту мовленнєтворення та референтної ситуації 
$(\mathrm{P})$, що його опосередковує. Сам комунікативний процес представлено рухом апроксимованої прямої інформаційного потоку від мовця до слухача в межах зображеного у вигляді півкола комунікативного простору промови за визначеними вище трьома площинами його реалізації, здійснюваними в руслі інформування, тобто площині нейтральної (0) презентації повідомлення. Темним фоном позначено можливі вектори розгортання мовленнєвої дії з більшим $(1+, 1-)$ чи меншим $(2+, 2-)$ відхиленням до площин позитивного $(+)$ або негативного (-) висвітлення об'єкту / референтної ситуації промови, зв'язки між якими та їхнє спрямування за будь-якого типу комбінування до сфери адресата позначено стрілками.

Розглянуті таким чином особливості розгортання тактичних ліній комунікативної стратегії збереження іміджу шляхом формування суспільної думки дозволяють зосередитися на конкретиці опису тї втілення комунікативними ходами. За першим способом у площині домінування інформації зі знаком «+» здійснюється:

1) пряма вказівка на позитивні якості предмета мовлення, самого мовця чи будь-кого іншого, що екстраполює цю характеристику на образ президента. Таку пропозиційно-змістову спрямованість висловлювання, кваліфіковану нами як КХ самопрезентації, ілюструє такий приклад: Today there are one point eight million fewer people on welfare than there were the day I took the oath of office. We are moving people from welfare to work (Clinton, 1996);

2) зміщення уваги слухача на аргументи чи факти для виправдання певних вчинків, наявної ситуації тощо, функціональну основу чого закладено в КХ відведення критики. Наприклад, Because we acted to defend our country, the murderous regimes of Saddam Hussein and the Taliban are history, more than fifty million people have been liberated, and democracy is coming to the broader Middle East (Bush, 2004);

3) опис ситуації, коментар подій, викладення фактів із позитивного боку, позбавлених експліцитно вираженої самопрезентації та спрямованих на створення необхідної для сприйняття інформації атмосфери. За сутністю свого вербального втілення подібне номінується КХ аналіз-«плюс», що можна спостерігати в такому фрагменті: We're enjoying the highest level of business investment in history, and America has renewed its leadership in developing the vast new opportunities in science and high technology. America is on the move again and expanding toward new eras of opportunity for everyone (Reagan, 1984).
Обгрунтовану таким чином сукупність комунікативних ходів розгортання повідомлюваного 3 огляду на втілювані ними настанови позитивного характеру цілком логічно описати як тактичну лінію акцентування на позитивних рисах об'скта чи референтної ситуації промови, алгоритм актуалізації якої можна узагальнити такою схемою: $\mathrm{P}^{+} \rightarrow\left(\mathrm{M}^{+}\right) \rightarrow \mathrm{C}$.

За іншим виділеним нами видом, де тактична складова частина повідомлюваного покликана створювати негативну перспективу (що визначає конфігурації лексичних одиниць, поверхнево-граматичні форми й конструкції та інтонаційні комплекси, забарвлюючи їхні конотативні значення відтінками площини «-»), стратегічні засади президентського звернення втілюються шляхом:

1) розгляду ситуації з вираженням негативного ставлення мовця до описуваного, репрезентація якого забезпечується КХ аналіз-«мінус». Наочною ілюстрацією його втілення може слугувати такий приклад: We still have too many Americans who give in to their fears of those who are different from them. Not so long ago, swastikas were painted on the doors of some African-American members of our Special Forces at Fort Bragg (Clinton, 1996). Ha тлі висловлюваних негативних суджень досягається самопрезентація, та імплементується у свідомість реципієнта необхідність прийняття певної позиції, рішень тощо;

2) фіксації свідомості слухача на негативних наслідках чиїхось дій, вчинків, фактах, що роблять очевидною чиюсь винуватість, причетність тощо. Власне, тут часто моделюється образ ворога, яким може бути економічна, військова, терористична й такі інші загрози. Подібну пропозиційно-змістову основу висловлювань уналежнюємо до $\mathbf{K X}$ викриття, демонстрацію чого знаходимо в такому прикладі: This monstrous brutality is but the latest act in Colonel Qadhafi's reign of terror (Reagan, 1986). Аналогічну функцію виконує виділений нами КX звинувачення, приклад якого ілюструє такий фрагмент промови: His party is the party of the past, the party of memory. His speeches are generalities from Poor Richard's Almanac. Their platform, made up of old left-over Democratic planks, has the courage of our old convictions. Their pledge is to the status quo, and today there is no status quo (Kennedy, 1960).

Таким чином, представлений комплекс зазначених комунікативних ходів будемо розглядати як способи реалізації тактичної лінії акцентування на негативних рисах об'скта чи референтної ситуації промови 3 притаманною їй інформацією зі знаком «-», що розгортається за схемою: $\mathrm{P}^{-} \rightarrow\left(\mathrm{M}^{+}\right) \rightarrow \mathrm{C}$. 
Останньому виділеному нами типу властивий умовно нейтральний характер у порівнянні 3 двома попередніми, що виявляється в:

1) прямому заклику адресата діяти певним чином, прийняти думку тощо. Актуалізуються подібні настанови КХ спонукання, як це видно 3 такого фрагменту: And if you share that faith with me, if you share that hope with me, I ask you tonight for your vote (Obama, 2012);

2) непрямому заклику шляхом апеляції до базових цінностей, страху, що експлікується через застереження, прогнозування та подібні до них твердження щодо фактів найближчого майбутнього. Узагальнюючи функціональне навантаження таких висловлень, використаємо на їх позначення поняття КХ застереження. Наприклад, The needs of all cannot be met by a business party or a labor party, not by a war party or a peace party, not by a southern party or a northern party. Our deeds will meet our needs only if we are served by a party which serves all our people (Johnson, 1964). Подібною апелятивною модальністю забарвлено також і КХ прогнозування, приклад якого демонструє таке висловлення: Over the next few years, big decisions will be made in Washington on jobs, the economy, taxes and deficits, energy, education, war and peace, decisions that will have a huge impact on our lives and on our children's lives for decades to come (Obama, 2012).

3) формуванні віри в необхідність інтеграції спільних зусиль у розв'язання проблем, боротьбу 3 труднощами тощо. Втілення висловлювань із такою пропозицією ми розглядаємо як КХ кооперації. Наприклад, At stake are the lives of thousands, the liberty of a nation, and the principles and the values of all the American Republics (Johnson, 1965);

4) корекції світоглядних позицій адресата в бажаному напрямі шляхом створення футуральної перспективи. Тут конкретно-фактичне значення повідомлюваного, бувши наділеним модальністю впевненого спілкування, отримує особливу інтерпретацію. Про подію повідомляється як про факт виконання певних зобов'язань, досягнення бажаних чи очікуваних результатів у найближчому майбутньому, що демонструє приклад, кваліфікований нами як КХ обіцяння: I tell you that as long as I am President, we will hold high the banner of human rights, and you can depend on it (Carter, 1980).

Акцентуємо на тому, що іманентно властивій для цієї тактичної лінії апеляції $\left(\mathrm{P}^{0} \rightarrow \mathrm{C}\right)$ може передувати інформація з ознаками негативного $\left(\mathrm{P}^{-} \rightarrow \mathrm{P}^{0} \rightarrow \mathrm{C}\right)$ або, навпаки, виголошення позитивного ставлення мовця до референтної ситуації $\left(\mathrm{P}^{+} \rightarrow \mathrm{P}^{0} \rightarrow \mathrm{C}\right)$, аргументований виклад яких посилює апелятивно-персуазивний потенціал повідомлюваного.

Позначимо цей тип поняттям тактики театральності, зважаючи на відому в науковій літературі (Шейгал, 2004: 92) інтерпретацію політичної комунікативної події як створюваного мовцем театралізованого дійства, орієнтованого на досягнення високого рівня видовищності для емоційного відгуку й залучення адресата до цієї гри, а також здатність цього терміна органічно поєднувати й досить значно експлікувати адресованість до слухача й тією ж мірою адресантно-центристську природу вербального розгортання президентського звернення.

Висновки. Таким чином, можемо констатувати, що шуканий інвентар засобів реалізації інтенційної складової частини досліджуваних президентських звернень досить адекватно інтерпретується визначеною сукупністю комунікативних тактик і ходів. Їхній комплекс, власне, динамічні зміни й поєднання комунікативних ходів дозволяє президенту-мовцю залежно від його когнітивної бази, прагматичних настанов і певних ситуативних факторів позалінгвального порядку здійснювати загострення уваги слухача на ключових ділянках промови, створювати потрібні ціннісні орієнтири й викликати бажані реакції.

\section{СПИСОК ВИКОРИСТАНИХ ДЖЕРЕЛ}

1. Бацевич Ф. С. Основи комунікативної лінгвістики. Київ : Вид. центр «Академія», 2004. 344 с.

2. Гайкова О. В. Предвыборный дискурс как жанр политической коммуникации : дисс ... канд. филол. наук : 10.02.04. Волгоград, 2003. 211 с.

3. Горіна О. В. Когнітивно-комунікативні характеристики американського електорального дискурсу республіканців : автореф. дис. ... канд. філол. наук : 10.02.04 ; Харк. нац. ун-т ім. В.Н.Каразіна. Харків, 2008. 20 с.

4. Дементьев В. В. Фактические и информативные коммуникативные замыслы и коммуникативные интенции. Жанры речи. Саратов : Изд-во ГосУНЦ «Колледж», 1997. С. 34-44.

5. Иссерс О. С. Коммуникативные стратегии и тактики русской речи. Москва : Едиториал УРСС, 2003. 284 с.

6. Паршина О. Н. Стратегия формирования эмоционального настроя в президентской риторике. Риторика и культура речи в современном обществе и образовании. Москва : Флинта : Наука, 2006. С. 301-306.

7. Петлюченко Н. В. Харизматика: мовна особистість і дискурс : монографія. Одеса : Астропринт, 2009. 464 с.

8. Савчук В. І. Сутність понять «стратегія», «тактика» та «хід» у розрізі проведення експериментально-фонетичного дослідження англомовного президентського дискурсу. Теоретична і дидактична філологія : збірник наукових 
праиь. Серія «Філологія». URL: http://ephsheir.phdpu.edu.ua/bitstream/handle/8989898989/3232/\%D0\%A1\%D0\%B0\% D0\%B2\%D1\%87\%D1\%83\%D0\%BA.pdf?sequence=1\&isAllowed=y.

9. Славова Л. Л. Мовна особистість політика: когнітивно-дискурсивний аспект : монографія. Житомир : Вид-во ЖДУ ім. І. Франка, 2010. 357 с.

10. Федорів Я. Р. Лінгвістичні моделі дискурсу публічних виступів: нариси із сучасних культурно-мовленнєвих практик. Київ : ВПЦ НаУКМА, 2010. 188 с.

11. Фоменко О. С. Лінгвістичний аналіз сучасного політичного дискурсу США (90-ті роки ХХ століття) : автореф. дис. ... канд. філол. наук : 10.02 .04 ; Київськ. ун-т ім. Т. Шевченка. Київ, 1998. 18 с.

12. Bush G. W. President's Remarks at the 2004 Republican National Convention. September 2, 2004. URL: https://georgewbush-whitehouse.archives.gov/news/releases/2004/09/20040902-2.html.

13. Carter J. Acceptance Speech at the Democratic National Convention. August 14, 1980. URL: https://millercenter.org/ the-presidency/presidential-speeches/august-14-1980-acceptance-speech-democratic-national.

14. Chaput C., Braun M. J., Brown D. M. Entertaining fear: rhetoric and the political economy of social control. New York : Peter Lang, 2010. 290 p.

15. Clinton B. Remarks at the Democratic National Convention. August 29, 1996. URL: https://millercenter.org/t he-presidency/presidential-speeches/august-29-1996-remarks-democratic-national-convention.

16. Johnson L. B. Acceptance Speech at the Democratic National Convention. Aug. 27, 1964. URL: https://millercenter. org/the-presidency/presidential-speeches/august-27-1964-acceptance-speech-democratic-national.

17. Johnson L. B. Report on the Situation in the Dominican Republic. May 2, 1965. URL: https://millercenter.org/ the-presidency/presidential-speeches/may-2-1965-report-situation-dominican-republic.

18. Kennedy J. F. Democratic National Convention Nomination Acceptance Address. July 15, 1960. URL : https://www.americanrhetoric.com/speeches/jfk1960dnc.htm.

19. Obama B. Acceptance Speech at the Democratic National Convention. September 6, 2012. URL: https://www.npr.org/ 2012/09/06/160713941/transcript-president-obamas-convention-speech.

20. Reagan R. W. Republican National Convention. August 23, 1984. URL: https://millercenter.org/the-presidency/ presidential-speeches/august-23-1984-republican-national-convention.

21. Reagan R. W. Speech to the Nation on Air Strikes Against Libya. April 14, 1986. URL: https://millercenter.org/ the-presidency/presidential-speeches/april-14-1986-speech-nation-air-strikes-against-libya.

22. Wodak R. The Discourse of Politics in Action. London : Palgrave Macmillan, 2011. 252 p.

\section{REFERENCES}

1. Batsevych F. S. Osnovy komunikatyvnoi linhvistyky [Fundamentals of communicative linguistics]. K. : Akademiia, 2004. 344 p. [in Ukrainian].

2. Gajkova O. V. Predvybornyj diskurs kak zhanr politicheskoj kommunikacii. [Electoral discourse as a genre of political communication] : diss. ... kand. filol. nauk : 10.02.04 / O. V. Gajkova. Volgograd, 2003. 211 p. [in Russian].

3. Gorina O. V. Kognitivno-komunikativni harakteristiki amerikans'kogo elektoral'nogo diskursu respublikanciv [Cognitive and communicative characteristics of the American electoral discourse of the Republicans] : avtoref. dis... kand. filol. nauk: 10.02.04 / Hark. nac. un-t im. V.N.Karazina. H., 2008. 20 p. [in Ukrainian].

4. Dement'ev V. V. Faticheskie i informativnye kommunikativnye zamysly i kommunikativnye intencii. Zhanry rechi. [Phatic and informative communicative ideas and communicative intentions] Saratov : Izd-vo GosUNC "Kolledzh", 1997. P. 34-44 [in Russian].

5. Issers O. S. Kommunikativnye strategii i taktiki russkoj rechi [Communicative strategies and tactics of Russian]. M. : URSS, 2003. 284 p. [in Russian].

6. Parshina O. N. Strategiya formirovaniya emocional'nogo nastroya v prezidentskoj ritorike. Ritorika i kultura rechi v sovremennom obshchestve i obrazovanii [A strategy for forming an emotional mood in presidential rhetoric]. M.: Flinta : Nauka, 2006. P. 301-306 [in Russian].

7. Petlyuchenko N. V. Haryzmatyka: movna osobystist i dyskurs [Charismatics: language personality and discourse] : monohrafiia. Odesa : Astroprint, 2009. 464 p. [in Ukrainian].

8. Savchuk V. Sutnist poniat "stratehiia", "taktyka" ta "khid" u rozrizi provedennia eksperymentalno-fonetychnoho doslidzhennia anhlomovnoho prezydentskoho dyskursu [The essence of the concepts "strategy", "tactic" and "move" for studying presidential discourse in tht context of experimental phonetics]. Theoretical and Didactic Philology. URL: http://ephsheir.phdpu.edu.ua/bitstream/handle/8989898989/3232/\%D0\%A1\%D0\%B0\%D0\%B2\%D1\%87\%D1\%83\% D0\%BA.pdf? sequence=1\&isAllowed $=\mathrm{y}$.

9. Slavova L. L. Movna osobystist polityka: kohnityvno-dyskursyvnyi aspekt [Linguistic personality politics: cognitive-discursive aspect]. Zhytomyr : Vyd-vo ZhDU im. I. Franka, 2010. 357p. [in Ukrainian].

10. Fedoriv Ya. Linhvistychni modeli dyskursu publichnykh vystupiv: narysy iz suchasnykh kulturno-movlennievykh praktyk [Linguistic models of the discourse of public speeches: essays on modern cultural and speech practices]: monohrafiia. K.: VPTs NaUKMA, 2010. 188 p. [in Ukrainian].

11. Fomenko O. S. Linhvistychnyi analiz suchasnoho politychnoho dyskursu SShA (90-ti roky KhKh stolittia) [Linguistic Analysis of Contemporary US Political Discourse (1990s)] Avtoref. dys... kand. filol. nauk : 10.02.04 / K.: un-t im. T. Shevchenka. K., 1998. 18 p. [in Ukrainian].

12. Bush, G. W. (2004). President's Remarks at the 2004 Republican National Convention. September 2. URL: https://georgewbush-whitehouse.archives.gov/news/releases/2004/09/20040902-2.html. 
13. Carter, J. (1980). Acceptance Speech at the Democratic National Convention. August 14. URL: https://millercenter.org/the-presidency/presidential-speeches/august-14-1980-acceptance-speech-democratic-national.

14. Chaput, C. et al. (2010). Entertaining fear: rhetoric and the political economy of social control. New York: Peter Lang, 2010. 290 p.

15. Clinton, B. (1996). Remarks at the Democratic National Convention. August 29. URL: https://millercenter.org/ the-presidency/presidential-speeches/august-29-1996-remarks-democratic-national-convention.

16. Johnson, L. B. (1964). Acceptance Speech at the Democratic National Convention. Aug. 27. URL: https://millercenter.org/the-presidency/presidential-speeches/august-27-1964-acceptance-speech-democratic-national.

17. Johnson, L. B. (1965). Report on the Situation in the Dominican Republic. May 2. URL: https://millercenter.org/ the-presidency/presidential-speeches/may-2-1965-report-situation-dominican-republic.

18. Kennedy, J. F. (1960). Democratic National Convention Nomination Acceptance Address. July 15. URL: https://www.americanrhetoric.com/speeches/jfk1960dnc.htm.

19. Obama, B. (2012). Acceptance Speech at the Democratic National Convention. September 6. URL: https://www.npr.org/2012/09/06/160713941/transcript-president-obamas-convention-speech.

20. Reagan, R. W. (1984). Republican National Convention. August 23. URL: https://millercenter.org/the-presidency/ presidential-speeches/august-23-1984-republican-national-convention.

21. Reagan, R. W. (1986). Speech to the Nation on Air Strikes Against Libya. April 14. URL: https://millercenter.org/ the-presidency/presidential-speeches/april-14-1986-speech-nation-air-strikes-against-libya.

22. Wodak, R. (2011). The Discourse of Politics in Action. London: Palgrave Macmillan, 252 p. 